\title{
O COMITÊ DE ARTICULAÇÃO FEDERATIVA NO GOVERNO LULA Os percalços da cooperação territorial
}

\section{Eduardo José Grin}

Fundação Getúlio Vargas (FGV), São Paulo - SP, Brasil. E-mail: eduardo.grin@fgv.br.

\section{Fernando Abrucio}

Fundação Getúlio Vargas (FGV), São Paulo - SP, Brasil. E-mail: fabrucio@gmail.com.

DOI: $10.1590 / 339703 / 2018$

\section{Introdução}

Desde 1988 há um paradoxo no federalismo brasileiro. De forma inédita nas federaçóes, os municípios transformaram-se em entes federativos, com status similar aos estados e à União. Contudo, a maioria das municipalidades não tinha todas as condiçóes para exercer esse novo poder político-administrativo e autonomia auferida. Assim, além das heterogeneidades que caracterizam o país em relação à geografia, à demografia e à desigualdade socioeconômica, o maior desafio federativo está no seguinte fato: a Constituição e as leis posteriores repassaram autonomia e a responsabilidade pela implementação de boa parte das políticas públicas aos

Artigo recebido em 28/11/2016

Aprovado em 22/08/2017 municípios, sem que a maioria deles tivesse, porém, capacidade administrativa e gerencial para realizar essa tarefa.

Este artigo aborda como o federalismo brasileiro lidou com a criação de arranjos de cooperação territorial voltados para promover o fortalecimento institucional dos municípios. $\mathrm{O}$ argumento a ser discutido é que relaçôes intergovernamentais organizadas por meio de fóruns federativos que são desprovidos de autoridade decisória e poder intragovernamental são pouco capazes de promover o desenvolvimento de capacidades estatais nos municípios. Em termos empíricos, o Comitê de Articulação Federativa (CAF) será a unidade de análise.

O CAF foi criado em 2003, no início do primeiro governo Lula, para gerar um "encontro de agendas" em torno do chamado "contencioso federativo". Este foi a base do Protocolo de Cooperação Federativa entre a União e associaçôes nacionais de representação municipal que gerou o Comitê de 
Articulação e Pactuação Federativa (Trevas, 2004). Considerava-se necessário institucionalizar um fórum para construir uma agenda compartilhada e uma contratualização federativa com os municípios para que deixassem de ser coadjuvantes construção de políticas públicas federais (entrevista 4).

Diferentemente das políticas sociais, em gestão pública e finanças municipais não havia nenhuma instância federativa, excetuada a Associação Brasileira das Secretarias de Finanças das Capitais (Abrasf). ${ }^{1}$ Os fóruns de coordenação federativa nessas áreas envolvem os Estados: Conselho Nacional de Política Fazendária (Confaz), Conselho Nacional de Secretários de Estados da Administração (Consad) e Conselho Nacional de Secretários de Estados do Planejamento (Conseplan). ${ }^{2}$ Esses são fóruns setoriais, mas não são organizados em bases de cooperação territorial, o que reforça o modelo do CAF como inovador diante da história da cooperação federativa no Brasil.

Com o CAF, a pactuação federativa adquiriu relevância política ao abrigar-se como instância consultiva da Casa Civil e da Secretaria de Relaçóes Institucionais (SRI) da Presidência, e com o comitê atuando como expressão direta do chefe de governo. Essa arena propunha-se a ir além da relação "nós dispomos, vocês demandam" (Pressman, 1975), pois visava apoiar uma nova organização pactuada do Estado nacional. Uma das tarefas para essa alcançar essa meta era fortalecer as capacidades institucionais dos municípios por meio de novos mecanismos federativos intergovernamentais (entrevista 4). Mas, quando comparado com as experiências alemã e autraliana em que os premiers e/ou presidentes dirigem as arenas de cooperação, o CAF não tem a mesma densidade política e constitucional.

O padrâo de relaçôes intergovernamentais almejado inseria-se em um novo ciclo de desenvolvimento em que os municípios teriam destaque na Federação. Os deficits de capacidade institucional municipal eram obstáculos para lidar com as desigualdades regionais. Justificava-se ser preciso avançar em direção a uma agenda de desenvolvimento institucional em um ambiente regulatório que complexificava a ação municipal (por exemplo, exigências do Estatuto da Cidade para modernizar a política urbana).
O CAF possui três níveis de gestão: o Pleno, a Secretaria Técnica e os Grupos de Trabalho. O Pleno é composto pelo Poder Executivo Federal e as entidades nacionais de representação de municípios. Conforme o Decreto n. 6.181/2007, que o instituiu, essa é a instância máxima de decisão formada por 37 membros, dezenove representantes do governo federal e dezoito representantes das três associaçóes municipais - Associação Brasileira de Municípios (ABM), Confederação Nacional de Municípios (CNM) e Frente Nacional de Prefeitos (FNP) - por meio de seus presidentes e mais cinco representantes para garantir representação regional. Regimentalmente suas decisóes ocorriam por consenso.

A Secretaria Técnica do CAF é formada pelos. Secretários Executivos das associaçóes municipais e representantes do Ministério da Fazenda, Ministério do Planejamento e Subchefia de Assuntos Federativos (SAF) da SRI. À SAF coube a Secretaria Executiva, embora sua estrutura organizacional e técnica fosse inexistente para tal função. Essa é uma diferença marcante diante dos casos alemão, suíço, sul-africano, canadense e australiano. Ademais, o CAF não tinha suporte constitucional que lhe conferisse autoridade decisória intergovernamental. O Decreto n. 6.181/2007, quatro anos após a sua criação, configurou um arranjo precário e, ao fim e ao cabo, dependente da vontade política presidencial.

A repactuação federativa (construção da "Federação renovada") era considerada central, e gerar capacidades estatais, especialmente "com foco nos pequenos municípios” (Losada, 2008, p. 11; Trevas, 2004, p. 5), era considerado um eixo-chave de nation building. Essa visão foi formalizada no Decreto n. 6.181/2007 (artigo 20): o CAF deveria sugerir procedimentos integrados para fortalecer a capacidade financeira, técnica e gerencial municipal. Esse tema está alinhado com a visão do GT para o Fortalecimento Institucional e de Qualificação da Gestão dos Municípios ${ }^{3}$ (SRI, 2011), o GT Interfederativo, ${ }^{4}$ criado pelo CAF em 2008: "Para a efetividade do federalismo são necessárias a constituição e o fortalecimento de mecanismos de articulação intergovernamental, um maior compartilhamento da gestão das políticas publicas e uma efetiva capacidade dos entes federados de realizarem suas competências constitucionais" (Idem, p. 9). 
De acordo com Trevas (2004, p. 6) e com o Relatório do GT Interfederativo (SRI, 2011, p. 11), a maioria dos municípios possuía fracas capacidades gerenciais para lidar com a descentralização político-administrativa e compartilhar a gestão das políticas. As iniciativas federais para ampliar os recursos de gestáo municipal seriam voltadas à capacitação e assistência técnica. Uma política nacional de fortalecimento institucional dos municípios apoiaria sobretudo os menores, considerados mais frágeis em termos gerenciais, para reduzir as desigualdades verticais e horizontais na Federação.

\section{Procedimentos metodológicos e sua operacionalizaçáo}

Segundo Gerring (2007), a análise do CAF pode ser considerada um pathway case, porque segue um caminho já existente em situaçôes similares. Onde já há uma hipótese confirmada em outras análises, a pesquisa pode se debruçar sobre casos nos quais o efeito causal pode ser isolado de outros potenciais fatores de confusão. Essa técnica de seleção e análise é concentrada sobre um único fator causal, denotado X1, que prevê o valor positivo de $Y(=1)$. Todas as demais possíveis causas produzem prediçóes "erradas" e são representadas por um vetor X2 de covariáveis.

Uma premissa essencial é a existência de casos já estudados, pois sobre as análises prévias se constrói uma seleção situada dentro de uma amostra já conhecida. Essa abordagem visa elucidar mecanismos causais explicativos aparentes nos casos conhecidos que, por essa razão, são "exemplos" de fenômenos mais amplos. Ressalte-se que a hipótese causal comparada não serve para dizer que se repetirão as mesmas condiçóes e explicaçôes em todos os casos. A rigor, trata-se de criar um criar um parâmetro para o estudo de caso em termos de variáveis e possíveis caminhos explicativos.

O CAF, nesse sentido, é um exemplo de experiências de cooperaçáo territorial em países federais, como são os casos alemão e australiano. Na Alemanha, as relaçôes territoriais têm suporte constitucional, como é o caso do Bundesrat (Conselho Federal) formado por representantes dos Lander (estados).
Essa instância possui poder de decisão vinculante sobre temas que envolvem a Federação e os governos subnacionais, cuja adesão a essa arena é compulsória. O Bundesrat é quase uma segunda casa legislativa (assembleia de membros dos gabinetes dos Lander, pois o parlamentarismo é o sistema de governo que elege premiers subnacionais). Ele possui poder de veto nas leis aprovadas pelo Bundestag (parlamento) de duas formas: por maioria na legislação geral (veto suspensivo) e por ausência de consenso entre seus membros na legislação que trata de temas de interesse dos Lander.

O Bundesrat é uma arena que toma decisóes de forma consensual (Wehllig, 1989). Sua base constitucional lhe confere poder intragovernamental e capacidade de enforcement sobre as agências centrais que formulam políticas públicas para os entes subnacionais. O Bundesrat assegura que os interesses dos Lander sejam abordados no processo de tomada de decisáo em nível federal, o que náo apenas reduz a dominância da esfera central (Schnabel, 2015), como amplia seus recursos políticos e institucionais para implementar decisóes junto às burocracias subnacionais.

$\mathrm{Na}$ Austrália, arenas de cooperação territorial datam da década de 1920, embora a trajetória mais recente destaque duas iniciativas: o Conselho de Governos Australianos (Coag), criado em 1992, e a Comissáo de Premiers de Estados (SPC), instalada em 2006. Ambos são fóruns de adesão subnacional voluntária nos quais conflito e cooperação são características de seu funcionamento, pois:

O processo cooperativo necessita direçáo e coordenação. Ele pode ser moldado por um conjunto de arranjos institucionais como encontros regulares e os "canais próprios" de consulta e esclarecimento, que são um conjunto de hábitos e normas, mas ele também é um processo de organização pelas pessoas interessadas em alcançar resultados particulares. Mover-se de um processo desmembrado para outro que coordene a produção de políticas em qualquer área requer alguns processos de construção de compromissos pelas pessoas interessadas (Painter, 1998, p. 63, tradução nossa). 
Para Painter (1998), esse seria um meio político e institucional para "cercar" as agências centrais e os ministros, de modo que essas instituiçôes investem recursos políticos e organizacionais para fortalecer essas arenas federativas. Este é um tema de gestão transversal difícil de implementar se esse fórum não tiver autoridade decisória, ainda que não constitucional como no caso alemão, mas indução e convencimento também são essenciais. Esta experiência mostra que as agências centrais se envolveram para criar esses "corpos intergovernamentais com mandatos nacionais".

O Coag é o ápice de um fórum intergovernamental formado pelo primeiro ministro, premiers estaduais, ministro-chefe dos Territórios e o presidente da Associação Australiana de Governos Locais. Suas decisóes são adotadas por unanimidade para ampliar a possibilidade de adesão. Sua estrutura de apoio técnico é formada por grupos de trabalho e comissóes permanentes para preparar agendas, propor políticas e alinhavar acordos.

Nos dois casos, o êxito associa-se a existência de recursos de poder decorrente do desenho político e institucional das arenas federativas sobre suas decisões, embora de formas distintas. No caso alemão, o mandato constitucional do Bundesrat, a definição de agendas federativas vinculantes e a presença obrigatória dos Lander conferem a esse fórum capacidade de enforcement quanto às definições adotadas. Por sua vez, a "armadilha da decisão conjunta", ao mesmo tempo que impede escolhas unilaterais dos entes diante do que foi ou não decidido thes confere poder de veto, o que influi na produção de decisóes consensuais.

No caso australiano, como a adesão é voluntária e as vinculaçóes constitucionais inexistem, ainda que seja uma arena institucionalizada, ele resultou de uma "intervenção centralista" induzi$\mathrm{da}$ pelo power of the purse (poder do dinheiro) da União (Painter, 1996) que, ao fim e ao cabo, funciona como um inibidor para a alternativa de saída unilateral dos governos subnacionais. Por um caminho distinto, capacidade de enforcement e busca de consenso federativo tornaram-se também a regra na experiência australiana.

O mecanismo explicativo da suficiência causal é que, onde são bem-sucedidas, essas arenas pos- suem poder intragovernamental (explica-se esse conceito na próxima seção) para implantar açóes que geram impactos intergovernamentais e nas relaçóes federativas. É suficiente observar esses casos para saber que, na inexistência de recursos de poder, instâncias de cooperação territorial são pouco capazes para conceber e implantar políticas públicas. Assim, o CAF será analisado como um exemplo de cooperação territorial sobre o qual se aplica o mecanismo explicativo do poder intragovernamental.

Este estudo foi organizado com base em dados secundários (documentos e propostas do CAF) e entrevistas com associaçóes de municípios e representantes do governo federal que participaram da construção e funcionamento desse fórum.

\section{Cooperação federativa territorial e promoçáo de capacidades estatais subnacionais}

\section{Caracteristicas e desafios dos fóruns de cooperação}

Fóruns de cooperação costumam ser formas que privilegiam arranjos políticos e institucionais entre os entes, visando criar iniciativas com abrangência federativa. Essas arenas definem suas regras de funcionamento e arbitram os temas que requerem pactuação entre o nível federal e os entes subnacionais. São espaços de negociação e barganha que definem a sua agenda e formas de deliberação, e não necessariamente se pautam por temas específicos, pois a representação territorial é o principal eixo político e organizativo.

Para Grodzins (1984), no federalismo cooperação significa que governos devem trabalhar juntos e a negociação entre eles precisa criar condições para obter esse resultado. Não sendo assim haveria antagonismo ou coerção, e ambas poderiam ampliar a ascendência do governo central e minar as bases da cooperação federativa. Por isso, para Burgess (2006), a metáfora do marble cake (bolo de mármore) também trata de interpenetração funcional, engajamento em políticas e nas relaçóes intergovernamentais no federalismo. O objetivo é construir instrumentos políticos e institucionais que assegurem a presença dos interesses territoriais na 
produção cooperativa de políticas. Esse processo seria menos centralizado nas decisóes que impactam os entes ao requerer instrumentos para ajustar as relaçóes intergovernamentais. Portanto, analisar como ocorre a implantação dessas relações é essencial, pois elas contêm questóes financeiras, políticas e sobre políticas públicas (Krane e Wright, 2000).

As demandas da cooperação se ampliam quando a produção de políticas pode gerar efeitos distintos entre os beneficiários. Essa questão política envolve interesses territoriais, mas também depende do desenho institucional do federalismo com suas regras e arenas decisórias. Em contextos de interdependência, a cooperação deve buscar como resultados "soluçóes mutuamente benéficas". Assim, "se todas as partes beneficiam-se da bem-sucedida realização de uma transação particular ou atividade, entâo, na prática, não importa se uma parte, tal como os agentes federais, gostariam de vincular-se à outra parte, tal como os governos subnacionais" (Agranoff e McGuire, 1998, p. 7, tradução nossa).

$\mathrm{Na}$ "gestão intergovernamental", uma das variáveis do modelo explicativo de Agranoff e McGuire (1998, p. 13) são as barreiras internas do sistema intergovernamental: fatores externos (dificuldades de os entes se ajustarem às normas para obter assistência) ou fatores internos (falta de recursos administrativos para realizar essas açóes).

A forma como arenas de cooperação territorial trata essas questóes que afetam desigualmente os governos subnacionais é uma variável política essencial para ampliar ou reduzir sua legitimidade e eficácia. A abordagem do modelo jurisdicional (territorial) é uma maneira de avaliar o êxito dessa forma de interação intergovernamental. Assim, "a inabilidade para remover barreiras internas para a atividade estratégica intergovernamental pode inibir o nível de atividade intergovernamental" (Idem, p. 16, tradução nossa).

Para Elazar (1994), equilibrar a diversidade de demandas de vários centros de poder territorial e domínios de políticas condiciona o perfil e a evolução das relaçóes intergovernamentais. Uma forma de amenizar a ocorrência de conflitos e gerar mais cooperação é constituir fóruns federativos com representantes de todos os níveis de governo. Esse pode ser um locus político e institucional para lidar com temas de dependência financeira subnacional e o apoio da Uniáo para implementar políticas (Duchacek, 1987).

Essas questôes desafiam a cooperação territorial, sobretudo se o poder dessas arenas para formular e implementar políticas enfrenta barreiras internas. Nessa linha, o conceito de poder governamental proposto por Berman $(2003$, p. 1) é útil: trata-se da capacidade de uma unidade de governo influenciar outras ou ainda a capacidade de um tipo de governo em defender-se ou promover seus interesses no sistema de relaçóes intergovernamentais. Se fóruns territoriais são desprovidos desses recursos de poder intragovernamental, reduz-se sua possibilidade de ação na arena intergovernamental, o que pode condicionar o alcance objetivo de suas decisóes. Se essas arenas não detêm recursos políticos e institucionais para implantar políticas, perdem em capacidade de indução e credibilidade junto aos governos locais.

Portanto, importa analisar como se organizam esses fóruns em torno da representação subnacional e as condiçóes que possuem para incidir nas relaçôes intergovernamentais. Dito de outra forma, não se pode superestimar esses fóruns, já que seus resultados práticos costumam ocorrer mais em campos funcionais de políticas e menos em interesses corporativos dos entes subnacionais, como territórios (Anderson, 1960).

Esse tipo de comitê pode ser útil para criar relaçôes federativas, mas não possui autoridade sobre políticas. Quanto à gestão de programas, esses fóruns não conseguem ir além de ser "pseudoarenas", pois não têm autoridade decisória e costumam prometer mais do que podem de fato definir. Tendem a ser pouco eficientes para promover a cooperação intergovernamental (Pressman, 1975, pp. 137-146, Elazar, 1962). Com efeito, a tomada de decisão costuma ressentir-se da falta de poder (intra)governamental.

Para Wright (1988), relaçóes intergovernamentais envolvem acordos em áreas onde a União oferece programas que demandam aceitação das esferas subnacionais. Como parte da barganha, os entes devem concordar com condições do tipo "fornecer fundos correspondentes" e "atender exigências de performance”. Portanto, a cooperação entrelaça temas de política (relações de poder entre territórios), policies (regras inseridas nas iniciativas federais) e 
administrativas (vínculos entre gestores). Mas para que a cooperação territorial conecte essas dimensóes são necessárias capacidades técnicas e organizacionais para estabelecer laços entre o governo central e suas contrapartes locais.

Por isso, Agranoff (2001) enfatiza que o conceito de território, sem mediação das policies federativas, pode reduzir sua utilidade explicativa, pois condições de acesso também dependem de regras inseridas em cada área de ação do Estado. Nesse caso, importa saber qual a possibilidade de compatibilizar a "parceria intergovernamental” focada nas "jurisdições” (territórios) com aquelas ancoradas nas "funçôes" (políticas). Essa questão é ainda mais significativa quando os vínculos entre governo federal e entes subnacionais são baseados na crescente ampliação de atribuições desses últimos. Uma das exigências colocadas para relaçóes intergovernamentais, quando constituídas sobre processos de descentralização de políticas, diz respeito às capacidades estatais dos entes subnacionais. Assim, açōes federais:

[...] para promover esses objetivos incluem assistência técnica para aumentar as capacidades estatais e locais para administrar e governar, além de outras políticas e programas que servem ao compromisso federal para construir capacidades - definidos como qualquer atividade federal (incluindo subvençóes, contratos e assistência técnica) cujo propósito é reforçar a capacidade de servidores públicos de governos locais, estatais e/ou federais gerenciarem seus programas para fornecerem serviços para seus eleitores ou para administrar suas responsabilidades jurisdicionais ou interjurisdicionais gerais (Burgess, 1975, p. 706, tradução nossa).

\section{A concepção de capacidades estatais}

Nesse artigo, o conceito de capacidades estatais baseia-se em Ingraham (2007). Trata-se da habilidade dos governos de: 1) utilizar e direcionar recursos públicos para os objetivos políticos desejados; 2) gerir programas e pessoas de forma eficiente; 3) avaliar se as metas governamentais estão sendo atingidas. Isso significa adquirir competências para que os governos cumpram suas finalidades políticas, organizacionais e legais, utilizando recursos disponíveis por meio de instrumentos adequados de gestão, visando gerar resultados à sociedade. A rigor, trata-se das chamadas atividades-meio (gestão financeira, gestão de pessoas, tecnologia da informação e organização administrativa). Segundo Kjaer, Hansen e Thomsen (2002), essas são "capacidades centrais" de gestão. Para Veloso et al. (2011, p. 18), "uma capacidade organizacional fundamental, cuja criação ocorre no longo prazo e é baseada em sistemas e atividades institucionais, sendo a gestão um de seus componentes principais".

A existência de burocracias organizadas é um bem escasso, o que remete ao tema dos incentivos à sua institucionalização. A construção institucional do Estado deve ser fortalecida diante das "deseconomias administrativas e organizacionais" que afetam o seu desempenho (Evans, 1993). Construir capacidades burocráticas não é uma estratégia conservadora, pois modernizá-las pode gerar retorno político aos governos (Idem). Mas se essas iniciativas partem do nível central, visando desenvolver capacidades institucionais em outros níveis de governo, podem ocorrer problemas políticos de aceitação. Essa situação demanda estímulos para ampliar adesóes, sobretudo em contextos federativos onde os governos locais têm autonomia política e administrativa (Haggard, 1998).

Capacidades estatais ampliam as possibilidades de atuação em domínios de políticas, geram mais autonomia de ação e reduzem a dependência de suporte externo, seja da sociedade ou de níveis superiores do governo. Mas essa visão não significa reforçar o autarquismo de unidades federativas, sob qualquer ponto de vista. Trata-se de avaliar em que medida mais capacidade estatal nos governos subnacionais permite uma combinação mais profícua entre "autonomia política com dependência das políticas públicas” (Wright, 1988) federais. Busca-se verificar a existência de recursos administrativos e financeiros para moldar a intervenção em políticas (Pierson, 1995) que, em países federalistas, costumam alinhar-se a certos a objetivos nacionais.

Como o federalismo cooperativo busca pactuar acordos entre os seus entes por meio de arranjos de corte territorial, em políticas públicas ou pro- 
gramas, a oferta de açóes para incentivar a modernização dos governos locais se insere nesse rol de possibilidades. E assim é mesmo que os entes subnacionais sejam autônomos, pois, como em todas as áreas, o pacto federativo se constitui não pela imposição das prioridades do nível central, mas por induções vistas como benéficas pelos entes. Portanto, as iniciativas federais para promover o desenvolvimento das capacidades estatais municipais se inserem nesse escopo mais amplo das relaçôes intergovernamentais, como segue na análise do CAF.

\section{O CAF e a modernização da gestáo municipal}

Os estudos realizados no GT Interfederativo resultaram, em 2010, na Agenda Nacional de Apoio à Gestão dos Municípios. O Relatório do GT Interfederativo (SRI, 2011, pp. 10-11) elencou diversos problemas listados no Quadro 1. O diagnóstico sugeria que os dois grandes gargalos estavam nas áreas de capacitação e assistência técnica federal. As dificuldades de acesso dos governos locais, sobretudo os menores, aos recursos federais era vista como um reflexo da baixa capacidade de gestão, mas as agências federais vinham enfrentando esse problema isoladamente.

Os resultados discutidos nesta seção se inserem nessa perspectiva de integração entre as unidades de governo, pois o CAF é uma estrutura de articulação, mas sem poder de comando sobre outros órgáos federais. As açóes para promover a "parceria intergovernamental" concentrada nas "jurisdiçōes" (territórios) não superaram os desafios de envolver as "funçóes" (políticas setoriais) nas iniciativas propostas. No Brasil, arranjos em torno de políticas públicas são a forma dominante de cooperaçáo intergovernamental.

O público-alvo definido pelo GT Interfederativo foram municípios com até 50 mil habitantes e considerados os mais carentes em termos de capacidades estatais. A proposta do CAF, para ganhar capilaridade federativa, demandava articulação intra-

\section{Quadro 1}

\section{Gargalos de Capacidade Estatal na Administração Municipal Brasileira}

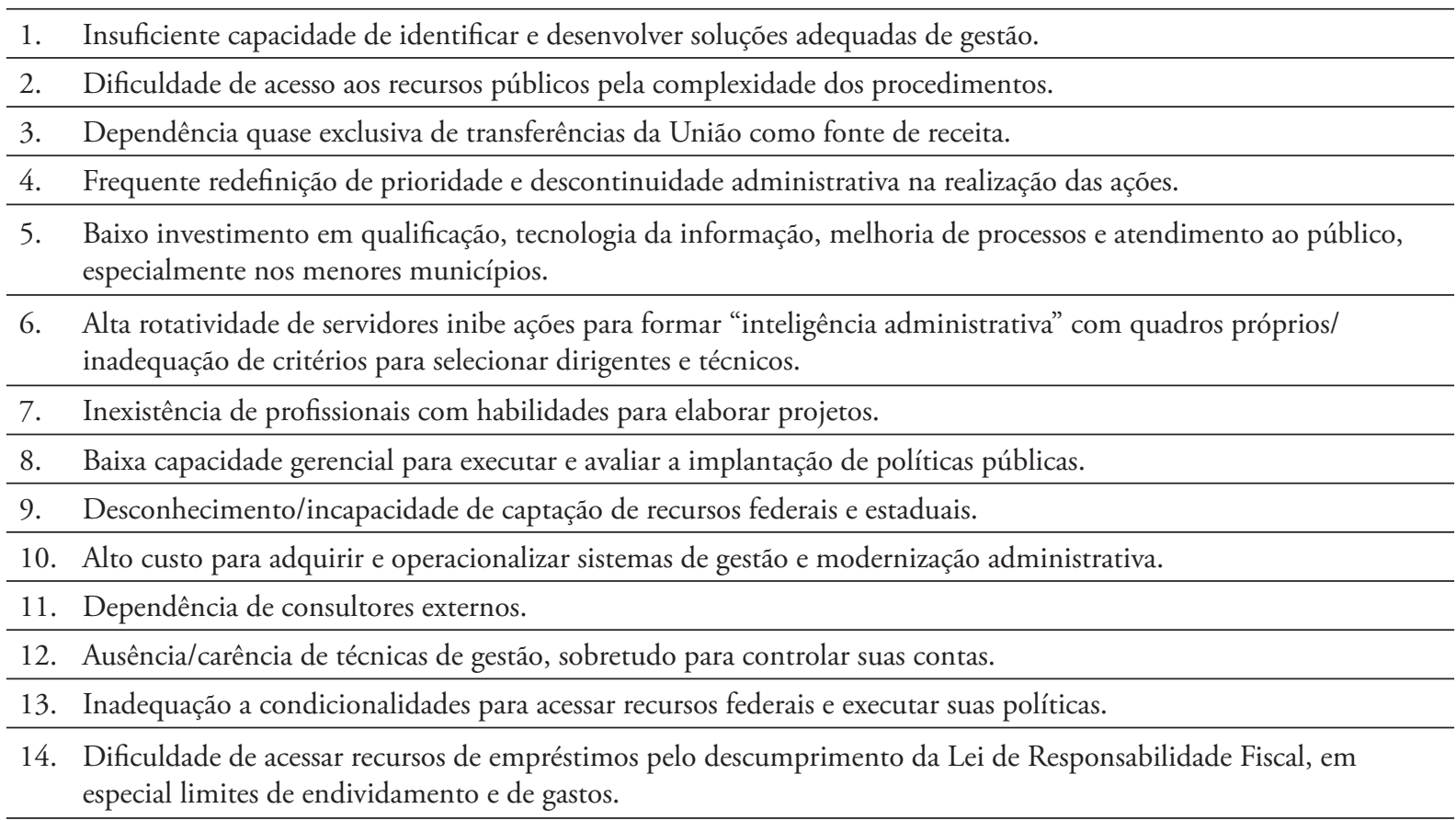

Fonte: adaptado pelos autores do Relatório do GT Interfederativo (SRI, 2011). 
governamental com os órgãos que tinham políticas de promoção da gestão pública municipal. Todavia, o CAF não possuía poder de comando sobre outros órgãos federais. Para o GT Interfederativo (SRI, 2011, p. 52), a Agenda de Apoio à Gestão Municipal deveria ampliar a capacidade de gestáo municipal para executar políticas públicas, bem como facilitar o acesso municipal aos programas federais, diminuir procedimentos desnecessários e unificar a habilitação, cadastro e tramitação por meio de quatro eixos, em duas dimensóes:

- uma agenda estruturante com três açóes: 1) criar referenciais de capacidade de gestão e o diagnóstico gerencial dos perfis municipais; 2) organizar a capacitação e a assistência técnica; 3) revisar os meios de acesso aos programas federais - convênios, Programa de Modernização da Administração Tributária e da Gestão dos Setores Sociais Básicos (PMAT) 5 com acesso simplificado e o "novo" Programa Nacional de Apoio à Modernização Administrativa e Fiscal dos Municípios Brasileiros (PNAFM). ${ }^{6}$

- uma agenda de açóes operacionais: 4) apoiar gestáo municipal por meio do novo portal de convênios e aplicativos disponíveis no software público $4 \mathrm{CMBr}^{7}$

A organização de GTs decorreu da visão de rede federativa defendida pelo governo e pela falta de estrutura técnica do CAF. Mas essa se mostrou uma frágil conexão intragovernamental e intergovernamental, pois a interação dos GTs com os órgãos federais pro- dutores de políticas foi limitada. Neste artigo a análise será centrada na produção do diagnóstico da gestão municipal e a tentativa de implementar a rede nacional de assistência técnica à gestão municipal.

\section{O diagnóstico dos perfis municipais de capacidades de gestão}

O principal resultado foi agrupar os municípios segundo características de capacidade gerencial para orientar a União na oferta de apoio mais adequada. A tipologia e a clusterização embasariam a Agenda Nacional de Apoio à Gestáo Municipal e a oferta de soluçóes ajustadas aos perfis das localidades (SRI, 2011). O Instituto de Pesquisa Econômica Aplicada (Ipea), o Ministério do Planejamento, Orçamento e Gestão (MPOG), a Caixa Econômica Federal e a $\mathrm{SRI}^{8}$ desenvolveram a metodologia para agrupar os municípios conforme capacidades de gestão/níveis de fortalecimento institucional. A prioridade deveria ser as pequenas cidades, pois para essas regras mais uniformes dos programas federais dificultavam sua adesão. Assim, era preciso propor alternativas:

[P]ara a superação, sobretudo nos pequenos municípios, das seguintes dificuldades: baixa capacidade arrecadatória; manutenção das contas; atuação dentro dos princípios da responsabilidade fiscal; modernização da estrutura administrativa; acesso aos programas federais, à tecnologia e às linhas de financiamento; incapacidade de elaboração de projetos e legislação; necessidade de constituição de quadro de carreira, de formação e capacitação de pessoal [...] (SRI, 2011, p. 4).

Tabela 1

Número de Variáveis em Cada Dimensão do Índice de Gestão

\begin{tabular}{ll}
\hline Dimensão & Número de variáveis \\
\hline 1 - Atuação dos gestores e gestão de projetos & 11 \\
\hline 2 - Capacidade de articulaçáo e clareza do seu papel federativo & 12 \\
\hline 3 - Disponibilidade de recursos & 5 \\
\hline 4 - Fortalecimento da estrutura institucional e processos de gestão & 22 \\
\hline $5-$ Indicadores socioeconômicos & 10 \\
\hline
\end{tabular}

Fonte: Relatório do GT Interfederativo (SRI, 2011). 
As dimensóes para agrupar os municípios foram: atuação dos gestores e gestão de projetos, capacidade de articulação e clareza do seu papel, disponibilidade de recursos, fortalecimento da estrutura institucional e processo de gestão. Definiram-se 37 indicadores, mas, como alguns foram inseridos em mais de uma área, o número de variáveis nas cinco dimensóes é o que está na Tabela 1 . Consideraram-se também indicadores socioeconômicos, apesar da sua baixa governabilidade, pois forneciam referenciais à ação governamental. Justificou-se que qualificar a gestão municipal com piores índices socioeconômicos traria benefícios maiores do que implantá-la em municípios mais privilegiados nesses indicadores.

Cogitou-se desenvolver um "Índice de Desenvolvimento da Gestão Municipal”, com base nesses indicadores e similar ao Índice de Gestão Descentralizada do Programa Bolsa Família (IGDM) que remunera os municípios por seu desempenho na gestão desse programa. Mas concluiu-se que a mensuração seria complexa, o que poderia gerar problemas de avaliação e repasse de recursos. Ademais, considerou-se que os melhores instrumentos de aferição de desempenho eram aqueles aplicados nas políticas públicas que aliavam incentivos com medição de desempenho (entrevista 1).

Por esse diagnóstico, as regióes Norte e Nordeste apresentaram os piores desempenhos. Nessas regióes há muitos municípios de pequeno porte, público prioritário para receber apoio da União, tendo em vista o foco de enfrentar as assimetrias regionais no acesso aos programas federais. Nas regióes Sul e Sudeste, percebeu-se a queda no desempenho gerencial à medida que os municípios afastavam-se das regióes metropolitanas.

O agrupamento dos perfis municipais segundo capacidades de gestão e nível de fortalecimento institucional é importante, pois ela pode ser atualizada e auxiliar as agências federais a avaliarem a gestão local. Considerando os resultados dessa ação estruturante, ela foi bem-sucedida na produção de um diagnóstico da realidade gerencial e institucional dos municípios, cuja distribuição no território nacional se encontra nas Figuras 1 a 4 .

Figura 1

Agrupamento dos Municípios na Dimensão “Atuação dos Gestores e Gestáo de Projetos”

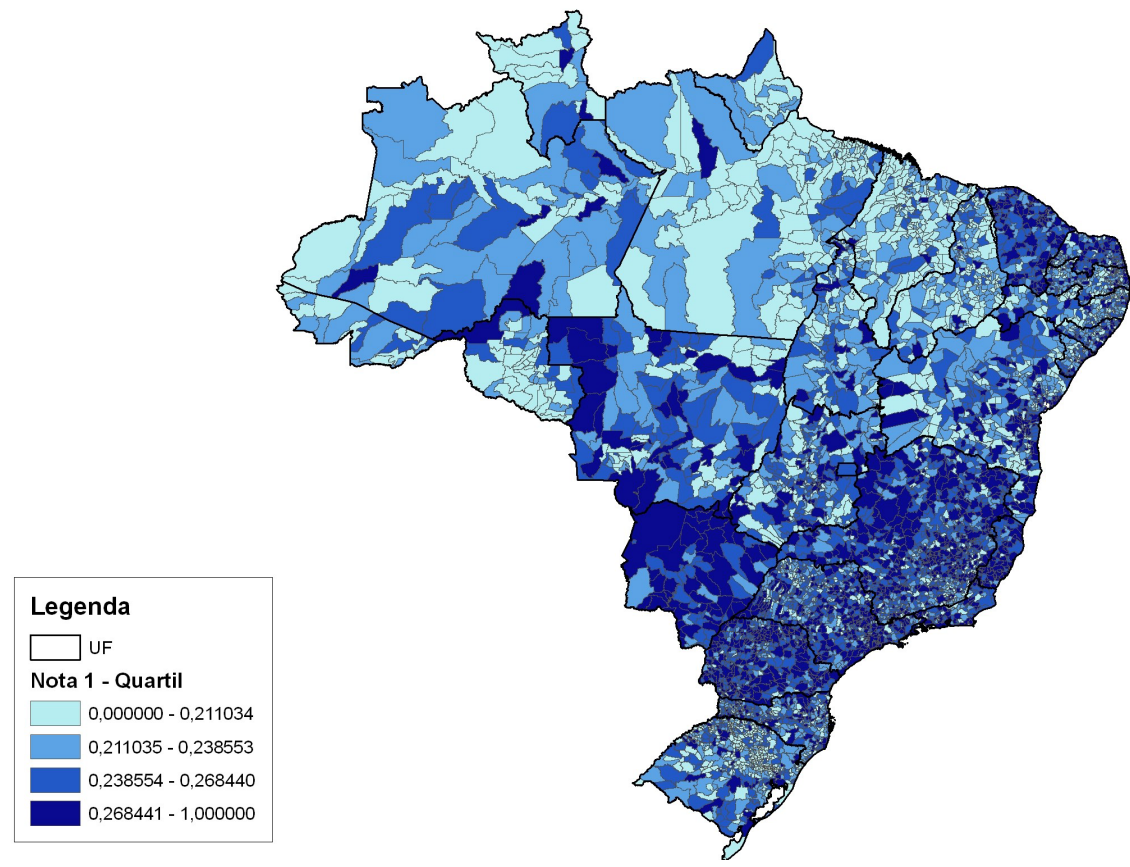

Fonte: Relatório do GT Interfederativo (SRI, 2011). 
Nessa dimensão avaliou-se se o município atende aos pressupostos para acessar verbas de transferência, financiamento e demais obrigaçôes legais, se possui gestores conhecedores das ofertas e políticas da Uniâo voltadas aos municípios, se seus gestores apresentam capacidade de elaborar, gerir e prestar contas de projetos desenvolvidos no âmbito municipal. Um fraco desempenho nesse índice poderia sugerir, por exemplo, políticas voltadas para capacitação em elaboração e gestão de projetos, para a divulgação mais cuidadosa das informaçóes a respeito dos programas e projetos da União no âmbito municipal ou a necessidade de uma política assistência técnica mais intensiva.

Nessa dimensão avaliou-se a necessidade de articulação com outros municípios e grupos locais. Também foi considerada a clareza das autoridades locais sobre o papel do município como ente federado. Para os municípios com fraco desempenho fraco nessa dimensão, políticas de fortalecimento da gestão poderiam incentivar a utilização de consórcios ou programas que facilitassem a troca de experiências de gestão com outros municípios. Entre os indicadores avaliados estavam: consórcios intermunicipais, contratos ou convênios com os governos estadual e federal em infraestrutura urbana, assistência social e meio ambiente.

Nessa dimensão, considerada um problema notável para fortalecer a gestáo local, aferiu-se a magnitude das carências. Municípios com índices mais baixos disporiam de condiçôes especiais para implantar açóes visando melhorar sua arrecadação e linhas de financiamento para sua modernização administrativa e qualificação dos recursos humanos. Foram mensuradas variáveis como a existência de cobrança de Imposto Predial e Territorial Urbano (IPTU), taxa de crescimento do valor da receita tributária total (própria mais transferências), arrecadação de receitas próprias em relação ao produto interno bruto (PIB), deficit ou superavit/receitas e proporção da dívida consolidada líquida/receita corrente líquida.

Figura 2

Agrupamento dos Municípios na Dimensão “Capacidade de Articulação e Clareza do Papel Federativo”

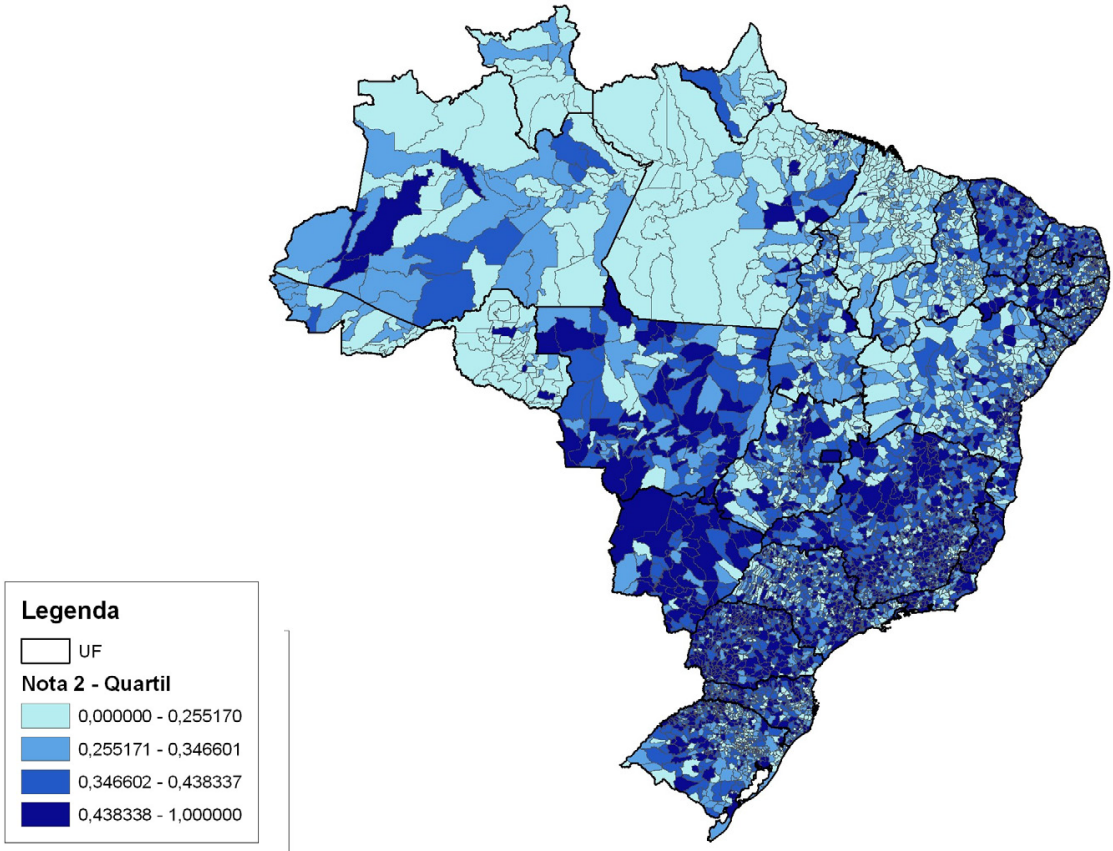

Fonte: Relatório do GT Interfederativo (SRI, 2011). 
Figura 3

Agrupamento dos Municípios pela Dimensão “Disponibilidade de Recursos"

\begin{tabular}{|l|}
\hline \multicolumn{2}{l|}{ Legenda } \\
\begin{tabular}{|l}
\hline uf \\
Nota 2 - Quartil \\
$0,000000-0,255170$ \\
$0,255171-0,346601$ \\
$0,346602-0,438337$ \\
$0,438338-1,000000$ \\
\hline
\end{tabular}
\end{tabular}

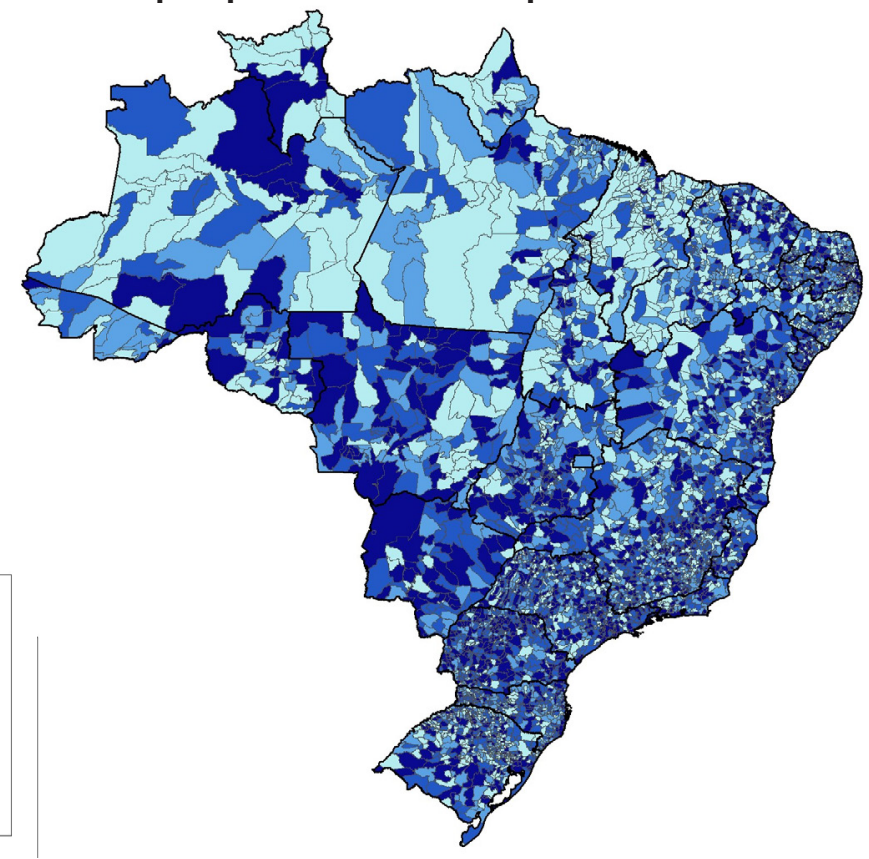

Fonte: Relatório do GT Interfederativo (SRI, 2011).

Figura 4

Agrupamento dos Municípios pela Dimensão "Fortalecimento da Estrutura Institucional e Processos de Gestáo"

\begin{tabular}{|c|c|}
\hline \multicolumn{2}{|c|}{ Legenda } \\
\hline & UF \\
\hline \multicolumn{2}{|c|}{ Nota 2 - Quartil } \\
\hline & $0,000000-0,255170$ \\
\hline & $0,255171-0,346601$ \\
\hline & $0,346602-0,438337$ \\
\hline & $0,438338-1,000000$ \\
\hline
\end{tabular}

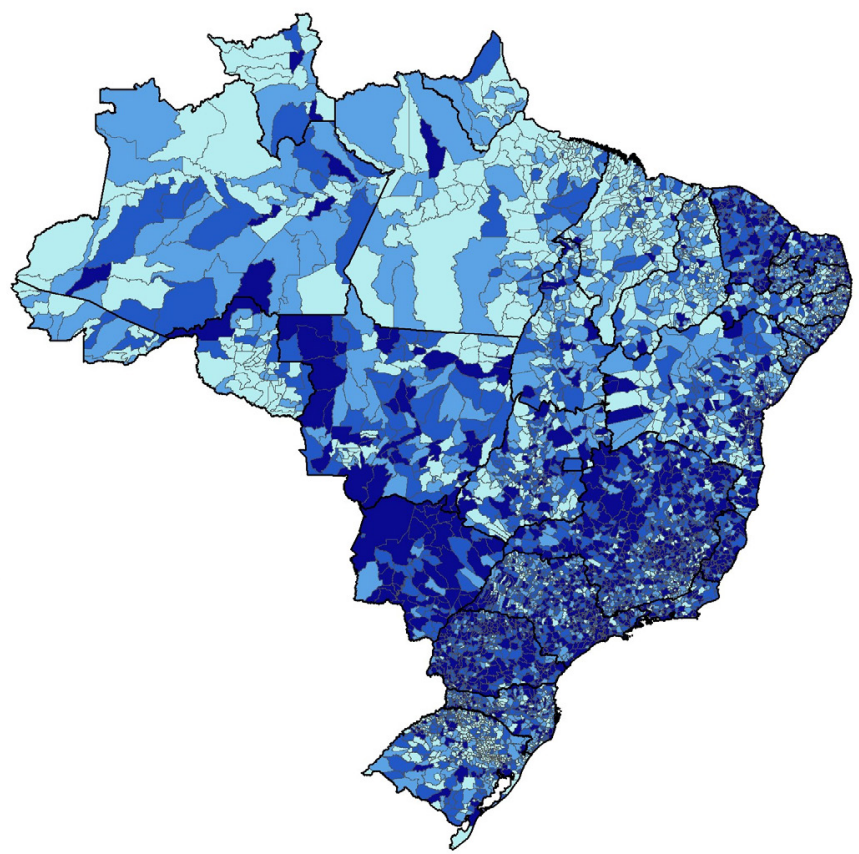

Fonte: Relatório do GT Interfederativo (SRI, 2011). 
Nessa dimensão avaliou-se a falta de continuidade das gestóes locais decorrente da sua baixa institucionalização. A solução seria estabelecer processos de gestão adequados. Um baixo valor sugeria medidas como incentivos à formação de uma burocracia municipal permanente e a formação de conselhos de políticas. Alguns indicadores utilizados foram: existência de cobrança de IPTU, taxa de crescimento do valor da receita tributária total do município, existência de convênios/contratos com a União e o estado para educação, habitação, meio ambiente e infraestrutura, existência de conselho e fundos nas áreas de habitação e saúde.

Mas a segunda fase, que deveria (re)formular e implantar ações para a gestão municipal, não logrou êxito. O CAF coordenou esforços de agências centrais para analisar as administraçóes municipais, mas não detinha capacidade decisória para pôr em marcha nenhuma ação. Esse problema manifestou-se na ausência de mudanças nos padróes de oferta inseridos nos programas e políticas federais que, quando houve, foram secundários para alterar o diagnóstico municipal. E assim foi porque a lógica da cooperação federativa no Brasil tem privilegiado vínculos intergovernamentais por meio de políticas públicas e secundarizado aqueles de cunho territorial.

A customização de produtos/serviços (o "cardápio de programas”) por clusters de municípios (porte populacional e capacidade de arrecadação) não avançou além da radiografia. Por exemplo, as mudanças no PMAT e no PNAFM implementadas gradativamente a partir de 2008 pouco alteraram as regras aplicadas indistintamente a todos portes de municípios. A cooperação federativa que poderia resultar do diagnóstico, ajustando açóes às diversas realidades de gestão municipal, não gerou nenhum resultado efetivo.

Essa articulação intergovernamental esbarrou nos seus próprios limites, pois estava além das competências do CAF mudar as normas de operação de crédito dos bancos públicos responsáveis pelos programas de modernização da gestão municipal. Uma alternativa para buscar solucionar essa questáo teve início em 2008, com a proposta da Rede de Assistência Técnica. Esse projeto visava ter capilaridade territorial para ofertar alternativas de aperfeiçoamento da gestão pública municipal.
A organização e coordenação de capacitação e assistência técnica

Esse eixo possuía dois focos: 1) aumentar a capacidade de gestão; 2) organizar uma Rede de Assistência Técnica para o atendimento customizado a distintos perfis municipais, visando articular ações que reduzissem a sobreposição de açôes e recursos federais. A ênfase seriam as "áreas meio" (administração fiscal e tributária, gestão de convênios e contratos, prestação de contas, recursos humanos, compras, elaboração e gestão de projetos e recursos tecnológicos). Uma condição necessária seria evitar o isolamento das açóes realizadas em órgãos como o Banco do Brasil, a Caixa Econômica Federal, a Controladoria-Geral da União (CGU), a Escola de Administração Fazendária (Esaf), a Escola Nacional de Administração Pública (Enap) e ministérios. Ou seja, "inserir o tema da "gestão municipal" de forma organizada e estruturada”. O Quadro 2 apresenta a justificativa da Agenda Nacional de Apoio à Gestão Municipal.

Buscava-se constituir o Programa Nacional Interministerial de Fortalecimento Institucional e Apoio ao Desenvolvimento da Capacidade de Gestão do Poder Municipal. O público-alvo seriam prefeitos, gestores e técnicos das secretarias de planejamento, administração e finanças. Mas a implantação da rede não foi além da proposta, pois ela requeria envolvimento técnico e financeiro de vários órgãos federais.

O ponto de partida seria diagnosticar as capacitações ofertadas pela União e cotejá-las com as necessidades da gestão local, mas essa análise não ocorreu, o que comprometeu a sequência do planejamento previsto. Deveria ser definido o perfil do público a se capacitar e as condiçóes organizacionais do município, pois isso seria um condicionante das possibilidades de formação, o que também não foi realizado. Por fim, priorizaram-se as cidades com mais de 150 mil habitantes participantes do Programa Territórios da Cidadania (PTC) ${ }^{9}$ para serem núcleos regionais de coordenação da assistência técnica. O PTC tangenciou a realidade da gestão municipal, mas acabou colocando à disposição dos governos locais programas para os quais não dispunham de capacidade de execução (entrevista 1 ). 
Quadro 2

\section{Motivaçóes para Apoiar o Desenvolvimento de Capacidades Estatais Municipais}

1. Baixa capacidade arrecadatória.

2. Dificuldade de manter suas contas e de atuar dentro dos princípios da responsabilidade fiscal.

3. Baixa modernização da estrutura administrativa.

4. Dificuldade de acessar programas federais (apoio em tecnologia e linhas de financiamento).

5. Incapacidade de elaborar, gerir projetos e legislar sobre assuntos de sua competência.

6. Ausência de quadro de carreira e capacitação de pessoal para executar as políticas públicas e qualificação para atender as demandas dos cidadãos.

Fonte: apresentação da SAF no Pleno do CAF em 19/11/2008 (CAF, 2008).

O modelo de assistência técnica assumiu uma enorme complexidade de gestão intragovernamental e intergovernamental. Seria necessário, em primeiro lugar, envolver órgãos como a Enap, o MPOG e o Ministério da Fazenda (MF) para participarem da revisão de suas ofertas de capacitação municipal. Em segundo lugar, o modelo dependia de uma rede de entidades (universidades, associaçóes de municípios ou ONGs para realizar o diagnóstico da gestão local). Em terceiro lugar, seria preciso alinhar esses esforços com o desenho do PTC, sendo que o objetivo desse programa não era promover a modernização da gestão local.

Um desenho com essa quantidade de ramificações intergovernamentais é uma variável dependente da capacidade de coordenação intragovernamental. Mas como o CAF não possuía estrutura técnica para um empreendimento federativo dessa envergadura, esse múltiplo apoio não logrou êxito. E isso explica a desarmonia entre a concepção e a implementação das políticas por ele apoiadas, o que limitou suas possibilidades, pois as propostas oriundas desse fórum gradativamente se tornaram pouco críveis para os órgãos federais e os municípios.

Nos termos de Burgess (2006), o diagnóstico não passou dos "relevantes aspectos do sistema". Havia acordo de que a "qualidade do federalismo" demandava mais capacidade estatal municipal, mas a solução proposta pelo CAF extrapolava seu poder de articulação. A combinação de ausência de autoridade intragovernamental com a perda de relevância que o tema assumiu na agenda do governo fede- ral criou impedimentos para implementar açóes de apoio à gestão municipal. $\mathrm{O}$ fato de os recursos de poder sobre políticas estarem nos ministérios também contribuiu para reduzir o peso da cooperação territorial proposta.

Obter a adesão de órgãos centrais foi difícil para um fórum federativo com limites de autoridade decisória e desprovido de capacidade técnica. A cooperação intragovernamental não foi a regra, como ilustra a passagem sobre o Relatório do GT Interfederativo: " $[\mathrm{O}]$ presente Relatório foi elaborado a partir de informaçóes obtidas junto a servidores que participaram à época do GT em questão, bem como, de dados extraídos de documentos, apresentaçóes e atas produzidas nas reuniōes do Grupo, uma vez que os atuais interlocutores do Ministério da Fazenda não estiveram presentes no desenvolvimento dos trabalhos do GT, no período de 2007 até a presente data" (SRI, 2011, p. 51).

Ademais, após 2007, o CAF estava mais debilitado em termos de legitimidade junto ao governo e entidades municipalistas, o que se tornou mais um limitador para levar adiante essa articulação intersetorial. Mesmo os êxitos que o CAF obteve na arena do federalismo fiscal ${ }^{10}$ entre 2003 e 2006 não foram suficientes para impulsionar açóes destinadas modernizar a gestão municipal. A visão que os municípios disporiam de mais recursos financeiros para viabilizar a adesão aos programas federais de modernização administrativa não se mostrou real. Em linha com Krane e Wright (2000), mesmo resultados fiscais e financeiros pouco contribuíram 
para uma "nova rodada para aumentar sua apropriação" pelos governos locais em direção a modernizar sua gestão.

Quanto à caracterização dos municípios-alvo houve um nexo de sua localização regional e porte com os indicadores socioeconômicos de baixa performance, grau de dependência das transferências financeiras federais e maior propensão a terem carências administrativas. Mas houve pouca ou nenhuma oferta de capacitação do governo federal para enfrentar essa situação (entrevistas 2 e 3 ). Essa delimitação de públicos é central, pois $89 \%$ dos municípios têm até 50 mil habitantes (IBGE, 2010) e foram definidos como prioridade.

Ao menos na concepção, o CAF se pautou por uma visão cooperativa de nation building que demandava a inserção dos municípios apoiada no desenvolvimento de suas capacidades estatais. Essa proposta está de acordo com a visão dos gestores do CAF e do municipalismo. Os municípios precisam de equipes de apoio permanente e para realizarem de forma efetiva a "execução de convênios [...], pois sozinhos não reúnem capacidades para tal" (entrevista 2). Seria preciso criar mecanismos públicos para assessorar grupos de prefeituras com equipes contratadas para apoiar a elaboração de projetos e sua prestação de contas, pois sozinhas não podem arcar com esse tipo de suporte técnico (entrevista 3).

Uma alternativa nessa direção foi a proposta do Programa Nacional Interministerial de Fortalecimento Institucional e Apoio ao Desenvolvimento da Capacidade de Gestão do Poder Municipal. Sua implementação deveria ficar a cargo de uma rede de órgãos federais, mas não avançou por requerer envolvimento técnico e financeiro dessas entidades. Conforme o projeto, a estrutura de gestão dessa Rede de Assistência Técnica seria responsabilidade do Núcleo Colegiado de Articulação Interministerial e de Coordenação Interinstitucional do Programa Nacional de Capacitação e Assistência Técnica em Planejamento e Gestão Municipal. ${ }^{11}$ Esse grupo era formado por SRI, MPOG, MF e BNDES, mas não havia representantes das associaçóes municipalistas. Esse fórum diretivo, que deveria ter funçóes técnicas (gerir capacitação e assistência) e políticas (articular ministérios e órgãos que atuavam nessas áreas), não se viabilizou, de modo que essa ação intragovernamental fracassou.
A experiência do CAF evidencia que relaçóes intergovernamentais são ancoradas na política e impregnadas de políticas públicas (Wright, 1975), mas a incapacidade de obter acordos na arena intragovernamental pode impactar a cooperação federativa. Por exemplo, trazer a Esaf, a Enap e o MPOG para o interior da Rede de Assistência Técnica não foi possível pela falta de poder intragovernamental e de capacidade de enforcement do CAF. Essa foi mais uma expressão da lógica prevalecente de cooperação federativa em bases setoriais, pois os órgãos de cada área dominam recursos para normatizar suas açóes, além de autonomia financeira para induzir o apoio a elas.

O papel atribuído à SRI para a gestão transversal e intragovernamental não tinha bases políticas, organizativas e financeiras que a amparassem. Isso para não falar que MPOG, BNDES e MF possuem seus próprios programas para a capacitação gerencial de municípios, enquanto o CAF e a SRI não tinham autoridade formal ou funcional sobre esses órgãos. Um exemplo nessa direção é o Programa de Apoio à Elaboração e Implementação dos PPAs Municipais, do MPOG. Essa iniciativa não foi debatida no âmbito do CAF para customizá-la como se previa.

Ademais, o MF e o MPOG implantaram vários programas de capacitação municipal sem qualquer consulta ao CAF, apesar de os dois ministérios integrarem a coordenação da Rede de Assistência Técnica. Alguns exemplos: Programa de Manutenção da Planta Genérica de Valores, Programa de Reforço da Capacidade Institucional em Municípios Selecionados para a Redução da Pobreza/Brasil Municípios, Programa Escola Virtual SOF/Curso Básico de Orçamento Público e Programa de Certificação Digital (MPOG); Gestão Orçamentária, Financeira e Contrataçóes Públicas para Municípios e Elaboração de Termos de Referência e Projeto Básico e Orçamento Público (MF).

A ascendência dos órgãos setoriais se sobrepôs ao modelo de cooperação territorial e o CAF não teve nenhum poder de veto sobre açóes que impactam os municípios, a exemplo do Bundesrat alemão em temas que envolvem os interesses dos entes territoriais (Whellig, 1989). Nesse caso, uma das razóes que explica a pouca capacidade de o CAF incidir na agenda de governo foi: "[...] não ter 
uma equipe permanente, burocrática [...] capaz de fazer a gestão desta instância. De produzir a pauta, de produzir convocatórias, de ter 'ritual'. Você não pode cuidar de uma instância complexa como esta de maneira [...] voluntarista. Não pode depender da disputa no dia a dia da agenda de funcionários, já bastante tensionados, para organizar esta instância que é complexa” (entrevista 5).

Completariam o modelo organizacional da Rede de Assistência Técnica: a SAF como coordenação técnica geral, os estados na mesa federativa ainda formada pela União, associaçóes estaduais de municípios, Tribunal de Contas dos Estados e Sebrae e um núcleo de suporte técnico que, a rigor, seria o comitê estadual do PTC. O programa seria descentralizado tendo por referência os colegiados territoriais do PTC onde os fóruns de prefeitos mobilizariam os gestores (Losada, 2013). Nos municípios seria organizada uma unidade executora com um escritório de projetos para convênios/contratos de repasse e uma equipe de apoio técnico (CAF, s/d). O foco seria ampliar a articulação intergovernamental e a cooperação federativa no planejamento e na gestão pública para organizar projetos que seriam implementados após aprovados pelo órgão gestor nacional. Mas esse arranjo intergovernamental complexo não se concretizou, assim como a própria Rede de Assistência Técnica não avançou além dessa formulação preliminar.

O desafio central para "um projeto dessa envergadura seria contar com o apoio técnico e financeiro de múltiplos parceiros", como o BNDES, a Caixa Econômica Federal, o Banco do Brasil, o Sebrae, associações municipalistas estaduais, governos estaduais e, claro, municipais. Sem esse suporte não seria possível qualificar os recursos humanos para elaborar projetos, implantar açôes de modernização da gestáo e melhoria da infraestrutura física e tecnológica das associações. Um órgão como o CAF não dispunha de competência política e legal para definir sobre como e com que aporte técnico e financeiro esse programa seria implantado.

Some-se aos constrangimentos políticos e institucionais do CAF para construir sua agenda federativa a "armadilha da decisão conjunta" como um dos fatores constitutivos de seu modelo decisório, pois suas deliberaçóes eram adotadas apenas por consenso. Ao contrário do caso alemão, as definições do CAF não tinham nenhuma garantia de que seriam implementadas, pois esse era um fórum de assessoria e consulta sem poder de adotar agendas vinculantes. $\mathrm{O}$ fato de a agenda da gestão municipal não gerar acordo entre os órgãos federais que compunham o CAF é um exemplo dessa "armadilha": ao não ser aprovada por consenso, seu efeito prático foi manter o status quo das açóes setoriais já implementadas por órgãos como a Caixa Econômica Federal, o BNDES ou o MPOG.

$\mathrm{O}$ caso do CAF mostra uma situação em que a pactuação federativa desejou igualar os atores políticos, mas acabou por induzir resultados pouco cooperativos cujo alcance, a rigor, não alterou a desigualdade federativa de acesso a programas. Diferentemente do caso australiano, esse modelo decisório não permitiu cercar "as agências centrais", pois como essas "escaparam" do CAF não se gerou um "corpo intergovernamental com mandato nacional”. Considerando essa experiência, Painter (1998) argumenta que essa capacidade política foi essencial para que as decisões da cooperação territorial fossem implementadas, o que se obtinha por meio de interações regulares de um grupo chave de órgãos federais com os governos subnacionais. No caso do CAF, com a perda crescente de legitimidade política a partir de 2007 o afastamento das associações municipalistas se ampliou.

Adicionalmente deve ser mencionada a interface das propostas do GT Interfederativo com o Programa Nacional de Gestão Pública e Desburocratização (GesPública), sobretudo em torno do "Guia referencial para implantação de indicadores de desempenho em gestão pública” voltado à gestáo pública, inclusive a municipal, na avaliação de suas capacidades estatais. Conforme GT Interfederativo (SRI, 2011, p. 49), construir métricas para aferir a gestão municipal é indispensável para (re)orientar as políticas federais que apoiam os municípios visando melhorar os serviços públicos. Todavia, a aproximação intragovernamental não ocorreu porque o MPOG implementou o GesPública sem interlocução com outros órgãos federais, e o CAF não dispunha de instrumentos técnicos ou políticos para alterar essa rota.

O desenho institucional do CAF explica muito de seus problemas, mas também deve ser conside- 
rado como se processa a coordenação intragovernamental no âmbito central. Como esse processo prioriza a cooperação por meio de políticas públicas, uma questão importante a avaliar é como e quais as capacidades de que os entes subnacionais dispóem para se articular nessas arenas. Isso porque, além de serem formas de cooperação setoriais, elas articulam unidades territoriais em torno de propósitos comuns em nível nacional.

A atuação do CAF esteve mais próxima de ser um corpo consultivo propondo políticas e estudos sobre a gestão municipal. No entanto, um fórum intergovernamental com essa limitação de poder intragovernamental não teria como dispor de recursos políticos para mediar acordos direcionados a constituir uma "Federação renovada", tal como se propôs em 2003. A distância entre suas intenções e a realidade dos resultados alcançados foi significativa. Desse modo, a questão das assimetrias de capacidades estatais municipais e das desigualdades federativas entre os maiores e menores municípios, que foi um dos eixos-chave de atuação do CAF, a ponto de constar do seu decreto de criação, não logrou êxito.

Conforme Agranoff e McGuire (1998), um critério para avaliar se a cooperação territorial detém recursos de poder intragovernamental é sua efetividade em remover barreiras governamentais internas. Quando se tratou de transferir os acordos intergovernamentais para a dinâmica intragovernamental, as agências federais assumiram as tarefas de regulamentar as decisóes pactuadas no CAF, o que gerou problemas na sua implementação. Quanto maior o hiato entre o CAF e as burocracias dos órgãos federais, menos cooperação intergovernamental foi gerada. Não ser exitoso ao enfrentar esses obstáculos pode inibir o nível de atividade intergovernamental, pois instâncias de cooperação federativa talvez não possuam recursos políticos para promover os interesses dos entes no interior do sistema governamental. Essa foi a realidade do CAF, conforme o conceito de poder governamental (Berman, 2003).

O diagnóstico de que a Federação brasileira carecia de uma arena territorial de cooperação intergovernamental com os entes municipais, pois as instâncias existentes eram setoriais ou voltadas apenas para envolver os Estados, não gerou um modelo efetivo de ação com o CAF. Ao longo da discussão, o principal argumento foi o de que fóruns como o CAF não dependem apenas da adesão territorial, mas, por serem transversais às políticas setoriais, demandam autoridade intragovernamental sobre órgãos como os ministérios. Em termos comparados com a experiência dos fóruns de cooperação territorial alemão, canadense e australiano, essa foi a principal razão do insucesso do CAF.

\section{Consideraçóes finais}

O artigo abordou como arranjos de cooperação territorial demandam poder decisório e intragovernamental para terem capacidade de enforcement nas suas iniciativas. Fóruns de cooperação intergovernamental organizados em bases territoriais precisam definir a forma como serão tratadas as disputas federativas e as regras do "conflito negociado" (Abrucio, 2005). Esta é uma condição necessária para ajustar como se decidirão questôes que afetam o nível central e as contrapartes subnacionais, mas são insuficientes para transformar essas arenas em canais efetivos para lidar com a desigualdade federativa.

Ainda que um modelo de "autoridade coordenada” (Wright, 1988) venha a ser adotado como caminho para gerar consenso em temas de alcance intergovernamental, a definição dessas regras não garante efetividade na implementação das pactuaçóes que foram geradas. Nessa linha, o argumento central foi de que se tais arenas não dispóem de autoridade intragovernamental dificilmente reúnem condiçôes para gerar políticas com efeito intergovernamental. Essa questão pode diferenciar fóruns com capacidade de enforcement daqueles que não passam de "pseudoarenas" (Pressman, 1975) ou "grupos de aconselhamento” (Inwood, Johns e O’Reilly, 2011).

Regras institucionais e o suporte legal desses fóruns importam, não apenas para indicar os constrangimentos à ação deles, mas sobretudo para viabilizar e manter suas decisóes no contexto das relações intergovernamentais. A indefinição dessa questão pode fazer com que tais instâncias restrinjam-se a fóruns de consulta, estudos e aconselhamento e sejam inefetivos nas relaçóes intergoverna- 
mentais. Assim, vale lembrar uma vez mai a ressalva de Anderson (1960, p. 15): os resultados de fóruns que reúnem entes territoriais costumam ser menores do que aqueles que são alcançados em arranjos federativos em campos funcionais de políticas.

As experiências alemã e canadense mostram que foram bem-sucedidas porque consolidaram-se como fórum de polities, alinharam policies e operaram na gestão intergovernamental ao dispor de capacidades técnicas e organizacionais para estabelecer laços entre o nível central e suas contrapartes locais. A reunião dessas três dimensóes depende da legitimidade política e federativa conquistada, mas decorre sobretudo das regras legais e/ou constitucionais que definem seu escopo decisório. Se forem desprovidos de recursos de poder intragovernamental, reduz-se sua possibilidade de atuar de forma efetiva nas relaçóes intergovernamentais, o que pode condicionar o alcance de suas decisóes.

A análise do CAF evidenciou que essa arena não possuía autoridade intragovernamental. Também não tinha estrutura técnica capaz de gerar vínculos verticais com as burocracias dos governos subnacionais que, na experiência do Bundesrat alemáo, diante da baixa capacidade executiva do governo federal, garantem a implementação das decisóes adotadas. O CAF não dispôs de um amparo legal maior (foi formalizado por decreto) e de capacidade organizacional para o enforcement de suas decisóes. Essa arena se ressentiu de autoridade política, pois na sua composição não estavam presentes lideranças políticas de governos subnacionais, como os premiers subnacionais no caso alemão.

Quando se fez necessária a construção de arranjos intergovernamentais com a participação de todas as esferas de governo, como ocorreu com a e a Rede de Assistência Técnica, o resultado foi uma paralisia decisória. O efeito foi não alterar o status quo federativo da falta de cooperação intergovernamental para atuar sobre as capacidades estatais municipais. E esse processo de pactuação federativa foi perdendo legitimidade junto a ABM, CNM e FNP, bem como a política de fortalecimento gerencial dos municípios se enfraqueceu na própria agenda do governo federal.

O CAF acabou se tornando uma "pseudoarena” por nâo dispor de mandato legal para intervir na política intragovernamental, nem de suporte técnico para incidir na implantação das decisóes que mediou ou para se aproximar das burocracias municipais. A criação de uma nova camada transversal de gestão intragovernamental e intergovernamental não conseguiu superar a força das instituições setoriais que já operavam no campo das políticas públicas voltadas a apoiar a modernização da gestão municipal. A proposta de criar uma nova instância que centralizasse e coordenasse setores do Executivo federal implicaria deslocamento de poderes no âmbito da presidência e conflitos na gestáo da coalizão governamental. Essa questão influenciou para que recursos institucionais e de poder voltados ao relacionamento com a gestão municipal seguissem na órbita dos ministérios que respondiam pelas políticas públicas. Assim:

[...] nos momentos em que o CAF tinha uma presença mais empoderada, que vários ministros iam à reuniấo e os prefeitos também, por isso se sentiam motivados para ir a essa reunião em função da capacidade de resolução, pois obviamente você tinha capacidade de tomada de decisão [...]. E ele vai se esvaziando e perdendo potência na medida que há uma mudança, uma inflexão, vamos dizer assim, do ânimo do governo federal na promoção do diálogo. [...]. Os ministérios já se faziam representar por funcionários de segundo, terceiro escalão. Os prefeitos foram se desmotivando a vir para participar destas reunióes, porque elas tinham um caráter mais simbólico e menos resolutivo [...]. Então houve um desempoderamento e praticamente acabou [...]. Ele não conseguiu se colocar como um processo crescente de robustez, de legitimidade, para construir estes pactos federativos (entrevista 5).

No caso brasileiro, a cooperação ocorre majoritariamente por meio de políticas públicas, e não por fóruns federativos de base jurisdicional, especialmente naquelas organizadas através de seus sistemas próprios. Esse é o caso da saúde e da assistência social, em que se institucionalizaram as comissóes intergestoras tripartites como arenas setoriais de pactuação federativa. Nessas instâncias, apesar do 
forte poder normativo e indutivo da União, ocorre a distribuição de recursos e o desenvolvimento de políticas para qualificar as capacidades estatais locais. Nesse aspecto, a experiência brasileira se diferencia bastante dos modelos alemão e australiano, pois a força das policies é maior que o poder das polities subnacionais em termos de arranjos de cooperação federativa.

Em linha com Arretche (2012), o peso do governo federal na criação de políticas públicas com baixa participação dos governos subnacionais é uma tônica desde a Era Vargas. Propor uma institucionalidade de cooperação territorial, no caso brasileiro, não reuniu recursos de poder para modificar essa dinâmica histórica que consolidou arenas setoriais de políticas públicas. Ao mesmo tempo, do lado dos governos subnacionais, a descentralização é vista mais como instrumento de poder (autonomia política e financeira) do que uma engenharia político-institucional de cooperação em políticas públicas. E esse é o outro lado da moeda que também influi para enfraquecer inovações na cooperação federativa.

Conforme o argumento proposto, a forma de cooperação territorial instituída pelo CAF não foi exitosa para promover capacidades estatais nos municípios por sua falta de poder intragovernamental. A proposta para a cooperação federativa não logrou êxito sustentável, apesar de ter obtido alguns resultados positivos. A inovação inicial não resistiu à fragilidade de uma arena sem poder transversal sobre os ministérios e a lógica setorial dos sistemas nacionais, que é mais forte do que fóruns federativos territoriais.

É igualmente importante destacar que a magnitude do empreendimento federativo proposto pelo CAF não tenha envolvido os estados, mesmo que estes fossem, no segundo governo Lula, majoritariamente de partidos de oposição. A construçáo de arenas federativas envolvendo os três níveis de governo é uma das bases institucionais dos sistemas de políticas, mas não serviu de inspiração para a proposta da cooperação territorial concebida pelo CAF. Como evidencia a gestão intergovernamental da saúde e da assistência social, a presença dos governos estaduais é essencial para vertebrar a cooperação federativa. Além disso, a presença desse nível intermediário de governo é essencial para compreender os êxitos alcançados nas experiências alemã, australiana e canadense.
Cotejando a discussão teórica com a análise empírica, as evidências geradas por esta pesquisa mostram que uma arena com as características do CAF não reúne os requisitos necessários ao menos para atuar na promoção de capacidades de gestão municipal. Diante da experiência internacional - e dada a relevância desse tipo de fórum ter que deter poder intragovernamental para incidir sobre questôes de desigualdade federativa, como é o caso das capacidades estatais municipais - institucionalidades como o CAF possuem recursos reduzidos de poder para atuar na arena intergovernamental.

\section{Notas}

1 A Abrasf não abrange todos os municípios e não envolve uma relação institucionalizada entre governo federal e os governos locais.

2 Uma análise mais detalhada desses conselhos pode ser encontrada em Abrucio e Sano (2011).

3 O referido GT foi criado pela Resolução CAF n. 4, de 6 de agosto de 2007, primeiro ano do segundo governo Lula, embora a publicaçáo do relatório tenha ocorrido em 2011, já na gestão Dilma Rousseff, razão pela qual as informações são referenciadas ao período 2007 2010.

4 O termo "interfederativo" se disseminou na burocracia federal, sendo utilizado em diferentes setores de políticas públicas em documentos e nome de estruturas, mas literalmente significa "entre federaçôes", ou seja, o uso não é apropriado para o contexto ou referências às relaçóes entre entes federados.

5 O PMAT assim se denomina desde 1999, quando, além das áreas administrativa e financeira, expandiu sua ação para a saúde, educação e assistência. O programa é ofertado pelo BNDES e a adesão dos municípios ao financiamento é voluntária.

6 O PNAFM foi criado em 2001, é gerenciado pelo Ministério da Fazenda e executado pela Caixa Econômica Federal. Seus recursos provêm do BID e as condiçóes de acesso são similares ao PMAT.

$7 \mathrm{O} 4 \mathrm{CMBr}$ visa o livre compartilhamento de conhecimento e cooperação entre comunidades. Daí os 4C: compartilhamento, conhecimento, cooperação e comunidade (disponível em antigo.softwarepublico.gov. $\mathrm{br} / 4 \mathrm{cmbr} /$ xowiki $/ \mathrm{tag} / 4 \mathrm{cmbr}$ ?popular $=1$, consultado em 30/8/2015). 
8 Pela Resolução CAF n. 4/2007 formou-se um subgrupo do GT com representantes ministeriais, Banco Nacional de Desenvolvimento Econômico e Social (BNDES), Caixa Econômica Federal, Banco do Brasil, Ipea, Serviço Brasileiro de Apoio às Micro e Pequenas Empresas (Sebrae) e municipalismo (ABM, CNM e FNP).

9 Lançado em 2008 para apoiar o desenvolvimento territorial/social, ações fundiárias, produção sustentável, saúde, saneamento, acesso a água, educação, cultura e infraestrutura via articulação federativa, de políticas públicas e participação social.

10 Por exemplo, a ampliação de $22,5 \%$ para $235 \%$ do repasse do FPM ou a repartição da Cide também com os municípios foram resultados oriundos da pactuação federativa coordenada pelo CAF.

11 A rede seria coordenada pela SAF, pelo BNDES e pelo Sebrae. Além da capilaridade territorial desse órgão incluiu-se um objetivo de suas açóes junto a micro e pequenos empreendedores: "Melhorar o ambiente de negócios [...] visando ao desenvolvimento local" (CAF, s/d, p. 1).

\section{BIBLIOGRAFIA}

ABRUCIO, Fernando L (2005), "A coordenação federativa no Brasil: a experiência do período FHC e os desafios do governo Lula”. Revista de Sociologia Politica, 24: 41-67.

ABRUCIO, Fernando L. \& SANO, Hironobu (2011), "A experiência de cooperação interestadual no Brasil: formas de atuação e seus desafios". Cadernos Adenauer, XII (4): 91-110.

AGRANOFF, Robert \& McGUIRE, Michael. (1998), "A jurisdiction-based model of intergovernmental management in US cities". Publius, 28 (4): 1-20.

ANDERSON, William. (1960), Intergovernmental relations in review. Minneapolis, University of Minnesota Press.

ARRETCHE, Marta T. S. (2012), Democracia, centralização e federalismo no Brasil. Rio de Janeiro, FGV/ Fiocruz.

BERMAN, David R. (2003), Local government and States: autonomy, politics, and policy. Nova York, M. E. Sharpe.

BRASIL. (2007), Decreto n. 6.181, de 3 de agosto de 2007. Institui o Comitê de Articulação
Federativa - CAF. Diário Oficial da União, 6 ago. Brasília.

BURGESS, Michael. (2006), Comparative federalism: theory and practice. Nova York, Taylor \& Francis Group.

BURGESS, Philip M. (1975), "Capacity building and the elements of public management". Public Administration Review, 35: $705-716$ (n. esp.: Policy management assistance: a developing dialogue).

CAF - Comitê de Articulação Federativa. (2007), Resolução CAF n. 4, de 6 de agosto de 2007. Institui o Grupo de Trabalho interfederativo com a finalidade de debater e formar uma ação sinérgica entre os diferentes atores envolvidos no fomento às açóes de fortalecimento institucional e qualificação da gestão dos municípios. Brasília, Secretaria de Relações Institucionais.

CAF - Comitê de Articulação Federativa. (2008), Agenda Nacional de Apoio à Gestão Municipal [apresentação da SAF no pleno do CAF]. Brasília, 19 nov.

CAF - Comitê de Articulação Federativa. (s/d), Rede de Assistência Técnica [mimeo].

DUCHACEK, Ivo D. (1987), Comparative federalism: the territorial dimension of politics. Nova York, University Press of America.

ELAZAR, Daniel J. (1962), The American partnership. Chicago, University of Chicago Press.

ELAZAR, Daniel J. (1994), "Federalism and the way to peace". Reflections paper, n. 13. Ontario, Institute of Intergovernmental Relations.

EVANS, Peter. (1993), "O Estado como problema e solução”. Lua Nova, 28: 107-156.

EVANS, Peter. (2003), "El hibridismo como estrategia administrativa: combinando la capacidad burocrática con las señales de mercado y la democracia deliberativa". Reforma y Democracia, 25: 7-32.

GERRING, John. (2007), Cases study research: principles and practices. Nova York, Cambridge University Press.

GRODZINS, Morton. (1984), The American System: a new view of government in the United States. Chicago, Rand McNally \& Company HAGGARD, Stephan. (1998), "La reforma del Estado en América Latina”. Reforma y Democracia, 11: 187-230. 
IBGE - Instituto Brasileiro de Geografia e Estatística. (2010), "Atlas do Censo Demográfico 2010”. Censos demográficos. Disponível em www.ibge.gov.br/home, consultado em 10/7/2015.

INGRAHAM, Patrícia W. (2007), In pursuit of performance: management systems in state and local government. Baltimore (MD), The John Hopkins University Press.

INWOOD, Gergory J.; JOHNS, Carolyn M. \& O'REILLY, Patrícia L. (2011), Intergovernmental policy capacity in Canada: inside the world of finance, environment, trade, and health. Montreal, McGill Queens University Press.

KJAER, M.; HANSEN, O. H. \& THOMSEN, J. P. F. (2002), "Conceptualizing State Capacity". Disponível em www.demstar.dk/papers, consultado em 16/6/2011.

KRANE, Dale \& LEACH, Robert H. (2007), "Federalism and intergovernmental relations: theories, ideas, and concepts", in J. Rabin, W. Bartley e G. J. Miller. (orgs.), Handbook of public administration, Londres/Nova York, CRC Press.

KRANE, Dale \& WRIGHT, Dale. (2000), "Intergovernmental relations", in J. Shafrtiz, (org.), Defining public administration: selections from the International Encyclopedia of Public Policy and Administration. Boulder (CO), Westview Press.

LOSADA, Paula Ravanelli. (2013), "Agenda Nacional de Apoio à Gestão Municipal”. Trabalho apresentado no XVIII Congreso Internacional del CLAD sobre la Reforma del Estado y de la Administración Pública. Montevidéu, 29 out.1 nov.

PAINTER, Martin. (1996), The Council of Australian Governments and intergovernmental relations: a case of cooperative federalism. $\mathrm{Pu}$ blius, 26 (2): 101-120.

PAINTER, Martin. (1998), Collaborative federalism: economic reform in Australia in the 1990s. Cambridge (MA), Cambridge University Press.

PIERSON, Paul. (1995), "Fragmented welfare States: federal institutions and the development of social policies". Governance: An International Journal of Policy and Administration, 8 (4): 449-478.
PRESSMAN, Jefrrey L. (1975), Federal programs and city politics. Berkeley (CA), University of California Press.

REDE de Assistência Técnica. Mimeografado. Brasília, s/d.

SCHNABEL, Johanna. (2015), "The intergovernmental safeguard's capacity to preven opportunism: evidence from eight federations". ECPR General Conference, Montreal, 26-29 ago.

SRI - Secretaria de Relaçôes Institucionais (2011), "Consolidação do Relatório do Grupo de Trabalho de Fortalecimento Institucional e de Qualificação da Gestão dos Municípios do Comitê de Articulação Federativa - CAF-2011”. Brasília, Presidência da República

TREVAS, Vicente y Plá. (2004), “O Governo Lula e a estratégia de fortalecimento da Federação: o caso do Comitê de Articulação Federativa”. Trabalho apresentado no IX Congreso Internacional del CLAD sobre la Reforma del Estado y de la Administración Pública. Madri, 2-5 nov.

VELOSO, João Francisco A. et al. (2011), Gestão municipal no Brasil: um retrato das prefeituras. Brasília, Ipea.

WHELLIG, Hans-Georg. (1989), "The Bundesrat". Publius: The Journal of the Federalism, 19 (4): 53-64.

WRIGHT, Deil S. (1975), "Intergovernmental relations and policy choice". Publius, 5 (4): 1-24. WRIGHT, Deil S. (1988), Understanding intergovernmental relations. Pacific Grove (CA), Brooks/Cole Publishing Company. 


\section{Entrevistas}

VICENTE Y PLÁ TREVAS, subchefe de Assuntos Federativos da Presidência (2003-2007) (28/7/2015).

PAULA RAVANNELLI LOSADA, assessora da Secretaria de Relaçóes Institucionais/Secretaria Executiva do Comitê de Articulação Federativa $(31 / 3 / 2015)$.

EDUARDO STRANTZ, coordenador de Estudos Técnicos da Confederação Nacional de Municípios (9/4/2015).

EDUARDO TADEU PEREIRA, presidente da Associação Brasileira de Municípios (13/5/2015).

GILBERTO PERRE, diretor executivo da Frente Nacional de Prefeitos (4/9/2015). 


\section{O COMITÊ DE ARTICULAÇÁO FEDERATIVA NO GOVERNO LULA: OS PERCALÇOS DA COOPERAÇÃO TERRITORIAL}

\section{Eduardo José Grin e Fernando Abrucio}

Palavras-chave: Cooperação federativa; Sistemas de políticas; Poder intragovernamental; Capacidade estatal; Municípios

$\mathrm{O}$ artigo discute como o federalismo brasileiro buscou promover capacidades estatais municipais no governo Lula (20072010) por meio da cooperaçáo territorial entre esses entes e a União. Analisa-se o Comitê de Articulação Federativa, que foi uma inovação no arranjo federativo com as municipalidades, mas cujos resultados, com o tempo, afastaram-se do propósito inicial. Com base na literatura internacional e no estudo do caso, argumenta-se que relaçóes intergovernamentais organizadas por meio de fóruns federativos sem autoridade decisória e recursos de enforcement intragovernamental reduzem sua capacidade de implementar açóes pactuadas com os entes. Este é um estudo qualitativo (pathway case) apoiado em explicaçóes causais de casos similares. Contribui-se com a literatura mostrando os limites das arenas intergovernamentais baseadas na lógica territorial, realçando que os sistemas nacionais de políticas públicas, presentes em algumas áreas, têm sido mais efetivos na cooperação federativa.

\section{THE FEDERATIVE \\ ARTICULATION COMMITTEE IN LULA'S GOVERNMENT: OBSTACLES IN TERRITORIAL COOPERATION}

\section{Eduardo José Grin and Fernando Abrucio}

Keywords: Federative cooperation; Policy systems; Intragovernmental power; State capacity; Municipalities

This article discusses how Brazilian federalism sought to promote municipal state capacities in Lula's government (2007-2010) through the territorial cooperation between such entities and the Union. It analyzes the Comitê de Articulação Federativa [Federative Articulation Committee], which was an innovation in the federative arrangement with the municipalities, but which results, with time, distanced themselves from their original purpose. Based on international literature and on the case study, it argues that intragovernmental relationships - when organized via federative forums without decision authority and intragovernmental enforcement resources - reduce its capacity to implement pact actions with other entities. This is a qualitative study (pathway case) supported by causal explanations of similar cases. It contributes with the literature on the subject by showing the limits of intragovernmental arenas based on territorial logic, emphasizing that national systems of public politics, present in a few areas, have been more effective in federative cooperation.

\section{LE COMITÉ D'ARTICULATION FÉDÉRATIVE DU GOUVERNEMENT LULA: LES MÉSAVENTURES DE LA COOPÉRATION TERRITORIALE}

Eduardo José Grin et Fernando Abrucio

Mots-clés: Coopération fédérative; Systèmes de politiques; Pouvoir intergouvernemental; Capacité de l'État; Municipalités.

Cet article aborde la façon par laquelle le fédéralisme brésilien a tenté de promouvoir les capacités administratives municipales pendant le gouvernement Lula (2007-2010) par le biais de la coopération territoriale entre ces entités et le pouvoir fédéral. Nous analysons le Comité d'Articulation Fédératif qui a été une innovation dans la structure fédérative avec les municipalités, mais dont les résultats, au fil du temps, s'est éloigné de l'objectif initial. Basé sur la littérature internationale et les études de cas, nous soutenons que les relations intergouvernementales, organisée par le biais de forums fédératifs sans pouvoir décisionnel et sans ressources de mise en place intergouvernementale, ont réduit sa capacité à assurer la concrétisation des actions concertées. Il s'agit d'une étude qualitative (pathway case) basée sur des explications causales des cas similaires. L'article contribue ainsi à la littérature en montrant les limites des arènes intergouvernementales basées sur la logique territoriale, démontrant que les systèmes nationaux pour les politiques publiques, présents dans certaines régions, ont été plus efficaces dans la coopération fédérative. 


\section{ERRATA}

RBCS vol.33 no 97/2018

DOI: $10.1590 / 339700 / 2018 E R$

E-location: e339700ER

- Nos artigos: "O comitê de articulação federativa no governo Lula: os percalços da cooperação territorial"; "Marcuse crítico de Weber: a política no capitalismo tardio"; "Representação política: a virada construtivista e o paradoxo entre criaçáo e autonomia"; "O pequeno investidor na bolsa brasileira: ascensáo e queda de um agente econômico"; "Ciências humanas e neurociências: um confronto crítico a partir de um contexto educacional"; "A peculiaridade do maquiavelismo inglês: das origens ao século XVII"; "Internacionalização de micro, pequenas e médias empresas inovadoras no Brasil: desafios do novo paradigma de desenvolvimento"; "A luta pelo reconhecimento e o paradigma da dádiva: uma proposta de articulação teórica" e "Determinantes individuais e de contexto da simpatia partidária na América Latina", assim como nas resenhas: "Um acerto de contas com o judiciário argentino", "A imprevisibilidade democrática" e "Idle No More: sobre a mobilização indígena no Canadá”, publicados na Revista Brasileira de Ciências Sociais, 2018, volume 33, número 97, cujos e-locations são respectivamente: e339703, e339704, e339705, e339710, e339702, e339706, e339708, e339709, e339711, e339715, e339716 e e339717, os prefixos do DOI estâo incorretos.

Onde se lia: "10.590"

Leia-se: "10.1590".

- No artigo "O comitê de articulação federativa no governo lula: os percalços da cooperação territorial”, com número de DOI: 10.1590/339703/2018, publicado no periódico Revista Brasileira de Ciências Sociais, 33(97): 1-22, nas páginas 9, 10 e 11 faltou inserir alguns pequenos textos depois das Figuras 1 a 4 . Os textos seguem abaixo:

\section{Depois da Figura 1 - página 9}

Nessa dimensão avaliou-se se o município atende aos pressupostos para acessar verbas de transferência, financiamento e demais obrigaçóes legais, se possui gestores conhecedores das ofertas e políticas da União voltadas aos municípios, se seus gestores apresentam capacidade de elaborar, gerir e prestar contas de projetos desenvolvidos no âmbito municipal. Um fraco desempenho nesse índice poderia sugerir, por exemplo, políticas voltadas para capacitação em elaboração e gestão de projetos, para a divulgação mais cuidadosa das informações a respeito dos programas e projetos da União no âmbito municipal ou a necessidade de uma política assistência técnica mais intensiva.

\section{Depois da Figura 2 - página 10}

Nessa dimensão avaliou-se a necessidade de articulação com outros municípios e grupos locais. Também foi considerada a clareza das autoridades locais sobre o papel do município como ente federado. Para os municípios com fraco desempenho fraco nessa dimensão, políticas de fortalecimento da gestão poderiam incentivar a utilização de consórcios ou programas que facilitassem a troca de experiências de gestão com outros municípios. Entre os indicadores avaliados estavam: consórcios intermunicipais, contratos ou convênios com os governos estadual e federal em infraestrutura urbana, assistência social e meio ambiente.

\section{Depois da Figura 3 - página 11}

Nessa dimensão, considerada um problema notável para fortalecer a gestão local, aferiu-se a magnitude das carências. Municípios com índices mais baixos disporiam de condiçôes especiais para implantar açóes visan- 
do melhorar sua arrecadação e linhas de financiamento para sua modernização administrativa e qualificação dos recursos humanos. Foram mensuradas variáveis como a existência de cobrança de Imposto Predial e Territorial Urbano (IPTU), taxa de crescimento do valor da receita tributária total (própria mais transferências), arrecadação de receitas próprias em relação ao produto interno bruto (PIB), deficit ou superavit/receitas e proporção da dívida consolidada líquida/receita corrente líquida.

\section{Depois da Figura 4 - página 11}

Nessa dimensão avaliou-se a falta de continuidade das gestóes locais decorrente da sua baixa institucionalização. A solução seria estabelecer processos de gestão adequados. Um baixo valor sugeria medidas como incentivos à formação de uma burocracia municipal permanente e a formação de conselhos de políticas. Alguns indicadores utilizados foram: existência de cobrança de IPTU, taxa de crescimento do valor da receita tributária total do município, existência de convênios/contratos com a União e o estado para educação, habitação, meio ambiente e infraestrutura, existência de conselho e fundos nas áreas de habitação e saúde.

\section{Na página 19, a Nota 10 contém erro.}

Onde se lia:

Por exemplo, a ampliação de 22,5\% para 235\% do repasse do FPM ou a repartição da Cide também com os municípios foram resultados oriundos da pactuação federativa coordenada pelo CAF

Leia-se:

Por exemplo, a ampliação de $22,5 \%$ para $23,5 \%$ do repasse do FPM ou a repartição da Cide também com os municípios foram resultados oriundos da pactuação federativa coordenada pelo CAF. 